\title{
Some recent responses to neoliberalism and its views on education
}

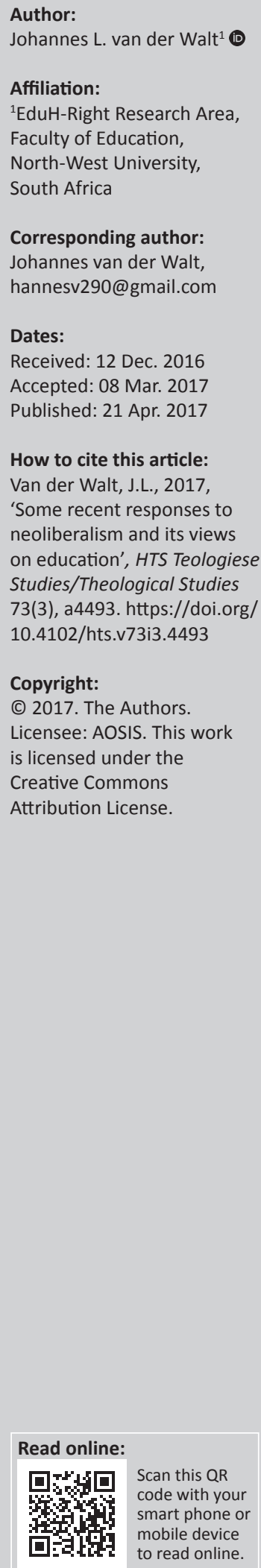

\begin{abstract}
This article is about developments that are on the rise in response to the global hegemony of the neoliberal approach to life in general and education in particular. After an outline of what neoliberalism entails and how it has impacted education, the discussion moves on to an outline of several of these new developments that are seemingly unrelated but at the deepest level seem to be critical of neoliberalism and its views about education. This is followed by a critical appraisal of these new developments. The appraisal, executed along the guidelines of the social space and ethical function theory, shows that these new developments, although they suggest a number of important corrections regarding neoliberalism and its views on education, are in themselves onesided and narrow. It is nevertheless important for educators and educationists to take account of such new developments that are in the process of changing our view of the world.
\end{abstract}

\section{Introductory remark}

We live in interesting times, politically, religiously, ideologically and philosophically speaking. We have hardly come to grips with postmodernism, post-postmodernism/postfoundationalism and neoliberalism as life and world views and now we find ourselves confronted with yet another development, namely an anti-neoliberal groundswell consisting of a number of seemingly unrelated incidents and events. As will be indicated below, this new 'movement' is gaining momentum in our life-world without us being aware of its rise and impact on our existence.

\section{Problem statement}

There have been several incidents and views in reaction to neoliberalism and its views about the world, the human being and education (to mention only a few of its impact areas). The problem is that many educators and educationists, after having lived and worked under neoliberalism for around four decades, do not have an accurate understanding of what neoliberalism entails, or how it has been impacting on education (in both the wider sense of guiding, equipping, forming, nurturing and unfolding [Nussbaum 2011:23]), and the narrower sense of teaching and learning). Many, if not most, educators and educationists have been so drenched in the neoliberal life and worldview that neoliberal sentiments have become part of their common sense (Maistry 2014:60-61) and hence is deemed by them to be a 'natural' way of seeing life and the world. It has become ingrained in everything that we do, including as educators and educationists (Ball 2003:223). It has colonised our minds as it were. Some new developments have, however, in recent times opened our eyes to the shortcomings and the challenges of neoliberalism. To understand what these new developments and incidences stand for and what they mean for education, we first need insight into what the term neoliberalism encapsulates and how neoliberalism has impacted worldwide on education during the past three to four decades.

In view of the above, the remainder of this article has been structured as follows. The next section contains a discussion of neoliberalism and how it has impacted on education (both as the act of forming and as a science). The section thereafter contains an overview of the main points of criticism against the neoliberal view of education. That is followed by a section in which the new developments and incidences are outlined in some detail. The penultimate section contains a discussion of their implications for education. The article concludes with a critical evaluation of the new developments and their expected impact on education.

\section{Neoliberalism: An outline}

Neoliberalism ${ }^{1}$ has been variously described: as a life view, a philosophy, theory, ideology, a set of ideas, a set of policies, a historical phenomenon, a term, a governing rationality, 'political reason',

1.Unfortunately, the scope of a single article does not allow space for a description of neoliberalism's capitalist, Protestant ethic and classic liberal roots, or of its history (the collapse of nation states; rejection of the welfare state; the rise of neoclassic liberalism; contributions by the Freiburg School of Economics, of the Chicago School of Economics, the Washington consensus and so on). 
'a governing form of reason', economic rationality, a doctrine and more (Boas \& Gans-Morse 2009; ${ }^{2}$ Hall 2011:18; Jones, Parker \& Ten Bos 2005:100; Maistry 2014:70; Marois \& Pradello 2015:1, 2; Palley 2004; Rustin 2016:153; Shenk 2015; Sparkes 2007:528; Welch 1998:157). It is an approach to life and the world that absolutises the economic aspect (modality) of reality at the expense of all others (Shenk 2015). In Adams's (2006:8) opinion, such reasoning is compelling because of its potential to combine economic, social, political and other dimensions of reality as a principle of legitimacy. In terms of this legitimacy, individuals are seen as rational choosers as consumers of education and knowledge - as long as this is done within the parameters of the logic and agenda of neoliberalism (Naidoo 2009:163).

Neoliberalism as an 'ideology' or 'philosophy' is grounded in the notion of the 'free, possessive individual,' with the state seen as oppressive in principle. The welfare state, occasionally referred to as the 'nanny state', in particular, is the arch enemy of the individual's freedom (Grayling 2010:216; Welch 1998:157). The state should never dictate to free individuals (citizens, the ordinary people) how to dispose of their private property, regulate a free market or interfere with their right to make profits and amass personal wealth. State-led social engineering must never prevail over corporate and private interests. It must not intervene in the 'natural' mechanisms of the free market (Hall 2011:10-11).

Neoliberalism has stealthily crept into the consciousness of many people, including educators and educationists, and is characterised by a managerialist discourse and vocabulary (Ball 2003:218). In many countries, modern existence has been characterised by a submission to the neoliberal agenda (cf. Naidoo 2009:163). Jansen (2009:147) agrees with Naidoo as far as the stealthy effect of neoliberalism is concerned; he refers to it as a form of 'mindless subservience' that has, according to Marois and Pradello (2015:11), 'seeped into our social and political fabric and affected our daily lives'. It has, according to Shenk (2015), 'irrigated every crevice of society', from banks to schools, from corporations to universities, from public agencies to individuals.

As Tan (2014:411) correctly stated, neoliberalism, including the human capital theory which it embraces, is not a mere theory in economics; it is a comprehensive approach to analyse a wide spectrum of human affairs in light of a particular mindset. It is a pervasive influence which the system of corporate power (often self-promoted as a free market) has gained over the state and civil society (Rustin 2016:154). In line with its globalist tendencies, neoliberalism has brought about a world with a single economics-inspired language (referred to in some circles as 'Globish', in others as 'Management speak' [cf. Sparkes 2007:528] and yet others as 'Global speak' [cf. Huntington 2005:267]), in which only one god, namely economy, trade and business, is served, where no national boundaries need to exist, where everyone is a rule to him- or herself, where individuals can achieve 2.No page number. and prosper and where human rights reign supreme (Diedericks 2016:5).

Neoliberalism has brought with it an instrumental agenda for education (Maistry 2014:63) in that education is seen as the instrument for serving the economic growth needs of a country, has to contribute to individual and national wealth, and assist individuals to utilise opportunities available and to make successes of their lives. Neoliberalism has furthermore led to the denationalisation of important segments of countries' academic, economic, trade and political elites and leadership (Huntington 2005:138). The extensive international involvements of business, academic, professional, media, non-profit and political elites lowered the salience of national identity for those elites, who in recent times have increasingly tended to define themselves, their interests and their identities in terms of transnational and global institutions, networks and causes (Huntington 2005:25-258). This, as we will see, has become one of the main targets of the new anti-neoliberal 'movement'.

Even the love of a mother for her child and religious affairs are not immune to the market orientation of neoliberalism (Tan 2014:432). Neoliberalism has percolated into education (Maistry 2014:61), thereby opening the door to the commercialisation and corporatisation of education, particularly higher education. It portrays schools and institutions of higher learning as businesses where demand is measured in terms of the number of applications, student registrations, throughput and subsidy income. It is concerned with the role of market forces in tertiary education and applies corporate managerialism; sees knowledge as a consumer item; prepares students for the labour market; sees students as clients and consumers of knowledge and credentials; sees research as part of the knowledge industry; and it speaks of knowledge branding, market share, the symbolic meaning of a product and the commodification of knowledge (Conradie 2011:424-432). In saying all of this, Conradie confirms an opinion of university vice-chancellor (at the time) Jonathan Jansen (2009):

The point of all this is that university-based intellectuals no longer work in the same kinds of campuses that, for the most part, were once sites of intellectual productivity, problem-setting and politics ... (p. 147)

Institutions of higher learning have been reconstituted as corporations and are expected to compete for resources and status in a market (ironically, in view of the remark above about the 'nannying state') regulated by the state (in terms of student numbers, quality assurance and subsidies for publications) (Rustin 2016:154). Institutions of higher learning have through the past four decades developed a neoliberal nomenclature: competitive advantage, competition within a regulatory structure, assessment for the purpose of ranking and rating, students as consumers or clients, enterprise culture, staff members as human capital or human resources, financial priorities, customer satisfaction, importance of management in achieving success (managerialism), fixed and part-time contracts, tighter controls over the 'workforce', accountability, financial investment (students invest in their own futures), 
higher production rates, productivity in terms of input over output, improved standards, recognition of market forces, performativity based on quantitative performance indicators, doing more with less, quality supervision and audits, systemic efficiency based on functionalist theory, flexibility, international competitiveness and responsiveness, total quality management, cost containment, neo-vocationalism, privatisation, monitoring systems, re-regulation and surveillance, entrepreneurship, productivity targets, competitive performativity, self-monitoring, the 'bottom line' - the list is endless (cf. Ball 2003:215; Lyotard 1984; Sparkes 2007:521; Welch 1998:170-171). The rationale of neoliberalism in institutions of higher learning [particularly the South African institutions of higher learning that Adams (2006:3)] is so concerned about) is to enact policy in such a way that the higher education system produces citizens who can effectively participate in the global economy.

Education (University) is seen in terms of its relative capacity to contribute to economic growth and individual and social involvement in education as an investment to be weighed against other possible areas of return (Welch 1998:158). The less directly economically quantifiable elements of education are either discounted or assigned an arbitrary economic value. Within the human capital theory (cf. Fevre 1997:20) that neoliberalism favours, individuals and societies are seen as 'rational' to the extent that they calculate how to maximise their return on their 'educational investment' (Welch 1998:158).

The following are typical manifestations of a neoliberal approach in tertiary/higher education, including university education:

- Institutions of higher learning are portrayed as businesses (Conradie 2011:424) or have even been reconstituted as business corporations (Rustin 2016:154) offering knowledge packaged and branded in the form of teaching programmes for consumption by interested clients (Conradie 2011:424).

- Higher education managers reach their positions after years of experience and promotion and on the basis of cogent (academic) argument and consensus. Many of these managers have leftist leanings and have been liberal academics earlier in their professions, and are sympathetic towards the demands of the students (but do not always have the means to meet those demands) (Solomon 2016:13).

- Management has been elevated to such levels that it has been referred to as managerialism (Jansen 2009:144); they work within new 'managerial regimes' (Rustin 2016:157). The authority of academics as well as of schools, faculties and deans has in the process been shifted from individuals working at the institution of higher learning to the broader management collective, the managerial complex. There has been a concomitant shift from the authority of academics in their own work to the greater surveillance of external authorities, such as national Councils of Higher Education (Jansen 2009:144). Managerialism finds expression in continuing improvement of the institution, its public image, its efficiency (financial costs), continual assessment of staff and programmes, adherence to externally accredited programs and processes, application of the 'reward and punishment system', improvement of efficiency and the closer linkage between education and the economy (Adams 2006:8). The overall mantra of managerialism is total quality management (Welch 1998:171).

- Although institutions of higher learning are supposed to enjoy institutional autonomy, the government (in the form of departments of education) expects the autonomy to be exercised in tandem with public accountability. Institutions of higher learning are expected to adhere to quality assurance through adhering to external procedures and mechanisms, and this transforms these institutions into organs with less autonomy (Adams 2006:4).

- In many cases, institutions of higher learning elites, like elites in business, corporates, politics and economic and other spheres, have their eyes on the significant expansion of international connections, academic exchanges, the international status of their institutions, investment and communication, usually labelled as globalisation. This has substantially changed the tertiary education environment in the past four decades and has many consequences for the identities of institutions of higher learning and all associated with them. As Huntington (2005:257) has argued, these extensive international involvements of these elites have lowered the salience of national identity for these elites who increasingly tend to define themselves, their interests and their identities in terms of transnational and global institutions, networks and causes.

- Everything that is done at the university is subject to processes of performativity whereby 'optimizing the system's performance' becomes the ultimate goal of the institution, and the technology for doing so is found in the discourse of business and management (cf. Lyotard 1984:xxiv). Performativity is a technology, a culture and a mode of regulation that employs judgements, comparisons and displays as means of incentive, control, attrition and change, based on rewards and sanctions (both material and symbolic). The performances of individuals and institutions of higher learning serve as measures of productivity or output, or displays of 'quality' or 'moments' of promotion or inspection (Ball 2003:216).

- Management of institutions of higher learning should be aware of the play of market forces (Conradie 2011:426). Among others, it has to understand that they work in conditions where resources 'have become far sparser' since institutions of higher learning became 'mass institutions' (Rustin 2016:150). They also have to recognise that the higher education system produces citizens who can effectively participate in a global economy (Adams 2006:3).

- Management should work towards productivity, even if it means capital withdrawn from those humanities which do not bring the expected income (Conradie 2011:L 427). There is a demand for 'modern' subjects such as economics and political science, and for the training of administrative elite (Rustin 2016:149). Subjects believed to be antipathetic to business values are discouraged or discontinued 
(Rustin 2016:150). Only entities that contribute to profitmaking consequently tend to dominate (Rustin 2016:153). Institutions of higher learning concentrate on occupations whose expertise lies in markets and regulation (Rosenzweig 1994:13; Rustin 2016:157). All of this is the result of institutions of higher learning striving for higher production values (Rustin 2016:158).

- Institutions of higher learning should be aware of consumer demand in terms of numbers of students, registrations, throughput and subsidy income (Conradie 2011:425). Higher learning activities are couched in consumerist ethos. Students are seen as clients and lecturers as sales consultants (Conradie 2011:426, 439). In many cases, students are seen as purchasers of qualifications and credentials since they (and the state) pay for their university education (Fevre 1997:20). According to human capital theory, education increases the productivity and earnings of individuals; therefore, education is an investment in individuals and also the key to the economic growth of the country (Tan 2014:412). Students invest in their own futures (Rustin 2016:155); they see 'learning as a financial investment' (Rustin 2016:158).

- After the 1960s, it was recognised that economic competitiveness depended on increases in knowledge in the workforce at large and on the contributions of research (Rustin 2016:150). Knowledge branding is important in a competitive market. Knowledge becomes commodified and branded (Conradie 2011:427, 432).

- Staff members are seen as factors of production, and they are 'paid what they are worth'. This is accomplished through application of the 'demand and supply' process (Palley 2004; Welch 1998:157).

- Managerialism claims that there is nothing distinctive about education; it can be conceptualised and managed like any other service or business institution (Adams 2006:8). Education is seen as a sorting and grading process, natural to a class society (Rustin 2016:148). Neoliberalism has turned higher education into a precious commodity to which individuals aspire and hope to gain access (Naidoo 2009:163). This approach to education more often than not encourages rote learning and the application of mechanical modes of instruction (Welch 1998:162, 164). Learning is re-rendered as 'cost-effective policy outcomes' and achievement as a set of 'productivity targets' (Ball 2003:218). The curriculum is more practical and utilitarian (Welch 1998:162, 164). The students are assumed to be more interested in qualifications, grades and credentials than in true academic learning (Sparkes 2007:521).

- The purpose of education is essentially to provide the workforceneeded by the capitalist economy. Acculturation is defined as the acquisition of social and human capital (Rustin 2016:148-149). People are cast as human capital and hence constantly expected to tend to their own present and future value (Shenk 2015).

- Research is subject to competition through regulatory structures (such as the National Research Foundation in South Africa) (Rustin 2016:155). This is exacerbated by moves to rate and rank institutions of higher learning and university departments according to research excellence and then tie a proportion of the institution's overall grant to this rating (Welch 1998:167). In the process, these structures avail themselves of 'impersonal, other-directed measures of value' (Rustin 2016:156) and often inadequate and inaccurate quantitative performance indicators (Welch 1998:166) such as 'objective' peer evaluation for purposes of rating and ranking and the number of articles published (Sparkes 2007:521).

- Many institutions of higher learning have adopted an entrepreneurial and enterprise culture (Rustin 2016:156).

It is clear from the above that neoliberalism has deprived education (in both senses, as mentioned) of its distinctive status as an interpersonal relationship that forms, guides, equips and unfolds less mature people for their life-task by morphing it into an enterprise intended to prepare people for the labour market, and in doing so, serving the interests of business, trade and the economy.

\section{A critical appraisal of neoliberalism and its views on institutions of higher learning and education}

A few critical remarks about neoliberalism are in order since they pave the way towards understanding the rise of the anti-neoliberal developments that will be discussed below.

Firstly, schools and other institutions of learning may not be reduced to business corporations and run according to business lines. The true meaning of education as forming, equipping, guiding and leading towards a higher purpose is sacrificed for the purpose of making education serve the economy, promote membership of a global community and serve as a sorting and grading process. Education is seen as a commodity, reduced to rote learning and memorisation, and inculcated through mechanical modes of teaching, aimed at measurable and cost-effective outcomes, mapped to productivity targets, with overemphasis on utilitarian subjects to the detriment of those aiming at forming the young person to be a fully developed person able to fulfil his or her calling in life, resulting in a view of students as merely chasing qualifications, grades and credentials.

Secondly, its view of reality is not only skewed but also reductionist: it sees everything as business and economy dominated, resulting in economic and business technologism, the absolutisation of the economic aspect of reality, overemphasis of achievement and efficiency, everything done for the sake of providing a workforce for the economy and so on. Its view of the human being is similarly skewed and narrow: the human being is seen as homo economicus, a client, consumer, investor in own future, an achiever and an instrument for economic progress.

Thirdly, of great importance are the shortcomings of the theoretical underpinnings of neoliberalism, which can only be mentioned in passing. Its ignorance of the twin principles 
of sphere sovereignty and universality and its confusion of value for true meaning in life and education can only be explained in terms of the theories in which neoliberalism has come to be grounded through the years: classic liberalism and individualism (Huntington 2005:46, 63ff.; Shenk 2015), neo-classicalism (Tan 2014:432, 436), utilitarianism (Bentham) (Tan 2014:415), capitalism (cf. Marois \& Pradello 2015:6), human capital theory (cf. Fevre 1997:14) and functionalist theory (Wright 2009:43-44). Important as these background theories are, we have to leave them by the wayside to attend to some of the new developments and incidences that have in recent times emerged in response to neoliberalism.

\section{Some recent anti-neoliberalist developments and incidences}

While neoliberalism still seems to dominate the economic, social, academic and political scene, there are signs of a strong resistance to it all over the world. However, the opposition to neoliberalism is still so tentative and unorganised that one could hardly describe it as a 'movement', as some observers have done (cf. Huntington 2005:143; Plaut \& Holden 2012:345; in different context Mahlomaholo [2014:171] spoke of 'fractured futures'). There is, however, reason to suspect that such a 'movement' is beginning to take shape, if one took into account all the recent events, opinions and publications in this regard. In what follows, an effort will be made to suture together some of these new developments and incidences that can be discerned in our life-world at this point in time.

By 2003, the national student organisations in South Africa had already changed from political protest-oriented structures to structures focusing on economic issues. Higher education fees had by that time already been identified as a stumbling block that required a national solution. Cele and Koen (2003:§35) predicted as far back as 2003 that the students' dissatisfaction with the status quo could lead to renewed mass protests as many student leaders had expressed open dissatisfaction with the limited role they played in addressing political and economic concerns.

According to Naidoo (2009:156, 163), herself a student activist, the student movement at first (up to around 2009) was defined by a transformation approach in accordance with the neoliberal agenda that the South African government and its Department of Higher Education had adopted (Adams 2006:7-8; Maistry 2014:66). This caused the movement to give up any hope of attaining the goal of free education. By 2009, however, the forces of disobedience to the neoliberal agenda have substantially grown among students to such an extent that most universities in South Africa were brought to a standstill in both 2015 and 2016 as a result of '\#FeesMustFall' and other '-MustFall' campaigns. Naidoo (2009) concludes:

When so many young people today are faced with such vulnerable and precarious living situations, disobedience and struggle (are) not a choice but a necessity ... the spirit of disobedience, refusal and rebellion embodied in the struggles of youth against apartheid no longer finds resonance within the (neoliberal) Congress movement. (pp. 166-167)
By 2009, the student movement in South Africa had signalled the beginning of the end of South African youth's subservience to neoliberalism. Significant here is the fact that the students demonstrated at important seats of power: the offices of the vice-chancellors of their universities as well as the Parliamentary premises and the Union Buildings, the seat of South African executive power.

Plaut and Holden (2012:345-358) take the story further by explaining that a movement had begun also in the underclass as a result of its disillusionment with the current African National Congress's (ANC) Black Economic Empowered nationalists (the new black elite). The poor and ordinary people clamoured for their voices to be heard but up to 2012 had had little hold over the mighty:

A new social movement ... a popular groundswell in support of the constitutional order or greater electoral success are just some of the things that could dramatically influence the balance of power. The ordinary people, including the students, are beginning to fight for their rights, to question authorities (including the university vice-chancellors and councils; cf. Solomon 2016:9-11), and shape their own destinies. (Plaut \& Holden 2012:355).

By 2016, Solomon (2016:11-12) could describe this as a new wave among students but sees it as 'fundamentally and violently anarchic'. He saw very little emancipatory rationale in the movement. In his opinion, nothing has prepared university managers to deal with the likes of the current 'fallists' ${ }^{3}$ when they view compromises on the part of university management as weakness and push for ever more concessions without giving anything in return (Solomon 2016:13).

In Cloete's (2016) opinion, the dissatisfaction because of the high university tuition fees formed part of the dissatisfaction about inadequate service delivery by authorities. Christie (2016) recently summarised the situation as follows:

... more than two decades (after the advent of full democracy in
1994), South Africa remains profoundly unequal, as is evident in
all dimensions of education provision. (...) The practices of
everyday life (including education) follow the rhythms of a
fundamentally unequal neoliberal political economy. (p. 435 , author's
own emphasis)

Plaut and Holden (2012:354) concur by saying that they perceive a rising tide of anger in the townships. People, including students, have taken to the streets in vast numbers to protest against poor service delivery.

Similar anti-neoliberal sentiments have risen elsewhere. Businessmen such as Donald Trump realised that the task of marketing is to spot the latest trends (such as the availability of social media by means of which half-truths in the form of 'fake news' can be spread [Huntington 2009:37; Rabe 2016:19], also referred to as 'post-truth' [Bezuidenhout 2016:17]), and mobilise meaning by attaching it to a particular 3.Students insisting on the reduction of fees and other things to be eradicated from campuses. 
product, typically on the basis of getting a celebrity, such as Trump, or a sport hero to underwrite the product (Conradie 2011:430). Political scientist Anthony Gaughan (2016) is convinced that Trump's election represents a populist revolt against immigration and free trade policies; there is increased and widespread public hostility to the political, media and business establishments that have governed the United States up to 2016. Trust in institutions is at an all-time low and a majority of Americans believe the country is headed in the wrong direction. In saying this, he confirms an observation by political scientist Samuel Huntington (2005) who wrote:

Globalisation, multiculturalism, cosmopolitanism, immigration, sub-nationalism and anti-nationalism have battered American consciousness. Ethnic, racial and gender issues came to the fore ... Corporate executives, professionals and Information Age technocrats espoused cosmopolitan over national identities. Their neoliberal statements and sentiments reflected the extent to which some people in American elite groups, business, financial, intellectual, professional and even governmental, were becoming denationalised and developing transnational and cosmopolitan identities superseding their national ones. This was not true of the American public, and a gap consequently emerged between the primacy of national identity for most Americans and the growth of transnational identities among controllers of power, wealth and knowledge in American society. (pp. 4-8)

Trump saw and took this gap.

The anti-neoliberal sentiment/groundswell has assumed such proportions in the United States of America after the unexpected election of Trump as United States' President in November 2016 and Brexit in June 2016 that Christine Lagarde, Executive Director of the International Monetary Fund, was compelled to say that globalisation has to 'get a new face' so that fewer people need to feel excluded from the world trade markets. While she feels this to be necessary, she sincerely hopes - in accordance with the neoliberal policies of the International Monetary Fund - that there would be no moves towards 'deglobalisation'. Lagarde also expressed concern about rightwing tendencies in Europe. She feared that political tensions about globalisation and trade could lead to negative or slow world trade (Bloomberg 2016). Her fears were partially realised when Italian Prime Minister Matteo Renzi's pro-European constitutional amendments were defeated in a referendum on 4 December $2016 .{ }^{4}$

Indian activist Arundathi Roy (2014) recently wrote in an anti-neoliberal vein:

The good news is that people have had enough and are not going to take it anymore. The Occupy Movement has joined thousands of other resistance movements all over the world in which the poorest of people are standing up and stopping the rich corporations in their tracks. This struggle has reawakened our imagination. Somewhere along the way, Capitalism reduced the

4.On the same day, however, the Austrian electorate rejected right-winger Norbert Hofer by electing Alexander van der Bellen as President. This was regarded in many circles as a 'liberal pushback' against the anti-neoliberal sentiment. Hofer nevertheless drew $46 \%$ of the votes. idea of justice to mean just 'human rights', and the idea of dreaming of equality became blasphemous. We are not fighting to tinker with reforming a system that needs to be replaced. (pp. 95-96)

The anti-neoliberalist 'movement' does not as yet have a fixed form or agenda, apart from the fact that it is in essence anti-neoliberal. The following can be discerned, however, as items that will be captured on an anti-neoliberal agenda somewhere in the near future:

- Everything that neoliberalism has stood for during the past four centuries will be heavily criticised and discarded, if and wherever possible.

- The power of the neoliberal elite/moguls will be replaced by people's power, if and wherever possible.

- Internationalism, globalism and cosmopolitanism will be replaced by nationalist ideals in the form of trade protectionism, an inward-looking tendency and isolationism. (Burundi and South Africa's intended withdrawal from the International Criminal Court is a step in this direction; cf. Huntington 2005:271.)

- Immigration will be curbed, resulting in xenophobic incidents, intolerance, inhospitality, patriotism, nationalism and populism.

- The economy might take a turn to the left, resulting in socialist policies (with the concomitant forms of inequality that it breeds), a turn away from utilitarianism and economism (the absolutisation of the economic aspect of reality and life). Labour will be seen in a different light.

- Most importantly, education will be seen in a different light, certainly not as ancillary to neoliberal ideas. It is doubtful, however, whether education will be approached as allembracing forming, equipping, guiding, nurturing and unfolding of the young. Experience has shown that education and education policy always tend to follow the official line of the powerful in society. There is reason to believe that the same will happen under any future antineoliberal political regime if it should come into power. In an ideal world, however, education should be prized for its own sake (Fevre 1997:20) as the formation of the whole person (Byrnes 2010:316), the result of the interplay between the person and the world (Byram 2010:318). Ideally, education should not be aligned to some or other economic or political agenda but be regarded in a genuinely open way as the most valuable real resource that people possess (Rustin 2016:148). At all levels, including that of higher education, education should be seen as an intergenerational gift to the upcoming generations, with intrinsic value, namely that it prepares for life, and not just for utilitarian purposes within an economics-dominated business environment.

\section{Discussion}

It is necessary to assess the new anti-neoliberal developments and incidences despite their immature condition at this point in time because this will help us steer developments, particularly in the pedagogical domain, in more productive 
and principled directions when confronted with such new developments. For this purpose, guidelines flowing from the social space and ethical function theory will be used. ${ }^{5}$

Firstly, it should be lauded that new movements have been taking up social space in our life-world, and that they are prepared to tackle neoliberalism and its deficient view of education head-on. There are indications that they seem to wish to occupy a larger space in reality, not one restricted to the political, social, economic and financial aspects of reality. This should be welcomed since that would lead to a more balanced view of education (see the last bullet of the previous section). Of import is also the fact that the proponents of the new developments and incidences are concerned about the fate of individuals, groups and societal relationships such as schools and institutions of higher learning. This provides a broader scope of action for education than the functionalist, technicist, instrumental, managerialist, performative, economised, market-determined, productivitydriven, human capital-driven, utilitarian, individualist and extreme capitalist view expounded by (some) neoliberals. This move harbours promise for a more balanced view of education in both senses: in the wider sense of forming, guiding and equipping, and the narrower view of teaching and learning. As mentioned, this move holds promise that the distinctive status of education will be restored, that it will no longer be seen as ancillary to business and economic interests. It also holds promise that the underlying pedagogical anthropology (view of the human being) will be broadened: from the restricted view of the human being as only homo economicus to a view of the human being as a complete and well-rounded, that is, fully educated being.

Secondly, in terms of the functions performed under the umbrella of these new developments, it should be lauded that there is a worldwide movement afoot to address the shortcomings of neoliberalism. However, it is lamentable that this function is restricted mainly to a redress of the political, financial and economic shortcomings and ailments of neoliberalism. In this, its scope at this point in time is just as narrow and reductionist as that of neoliberalism. It sees neoliberalism as the 'enemy' and attempts to combat it at every point but does not itself provide at this stage any constructive life-view perspectives that could be useful in a pedagogical context.

\footnotetext{
5.The social space and ethical function theory firstly suggests that individuals, groups and societal relationships such as families, the state, business, school, universities and societal relationships such as families, the state, business, school, universities
and sports clubs each occupies a particular social space in our life-world, without and sports clubs each occupies a particular social space in our life-world, without
thereby claiming a superior or overall (absolute, dominating) status for the social thereby claiming a superior of reality. The social is but one of the modalities of reality, and it is interwoven with all the others (cf. Mahlomaholo 2014:172-173). The theory secondly suggest that each individual, group or societal relationship has been entrusted with a creation mandate, function, aim, purpose and calling. Each should pursue its function and purpose with due diligence, responsibility and accountability and with due respect for the social spaces, self-determination and functions of all othe individuals, groups and societal relationships. This respect entails recognition of the twin principles of sphere sovereignty and sphere universality. The theory thirdly twin principles of sphere sovereignty and sphere universality. The theory thirdly suggests recognition of the ethical principle of diligent care of and for the interests of all other individuals, groups and societal relationships. This principle has been variously formulated as loving your neighbour as yourself (Mt 5:43), caring for the person and interests of the other (Stoker 1967:231), Kant's categorical imperative (Kenny 2012:699) or Rousseau's maxim of doing unto others as you would have them do unto you (Comte-Sponville 2005:9). This will afford social space for all individuals, groups and societal relationships to manifest and express their own meaning in life and hence contribute value in and for humankind.
}

Thirdly, ethically speaking, the new developments and incidences are not really constructive. It wishes to destroy the neoliberal ethos but has so far suggested very little in terms of an alternative approach to life and to education in particular. It is still an anti-movement, and this finds expression in its negative attitude towards life in general and neoliberalism in particular: its proponents speak of disobedience, ill-discipline, the use of fake news and posttruth. Its opponents blame it for its anarchism. It also has other traits that are ethically questionable: its readiness to pounce on market opportunities and to exploit dissatisfaction; its use of the social media to spread half-truths and to incite others to revolt; the possible xenophobia; intolerance and inhospitality that might result from its strategies; and the possibility that education also will be abused by the opponents of neoliberalism. The fact that proponents of these new developments and incidences seem to be deeply concerned about especially the poor is laudable on ethical grounds; its total and loveless rejection of the neoliberal elites is deplorable, however. Although these anti-neoliberal developments embody an important correction on neoliberalism, there is as yet not much constructive to be learnt from it in a pedagogical sense.

\section{Conclusion}

The rise of anti-neoliberal responses to neoliberalism and particularly the latter's approach to education affords us with an opportunity to prepare ourselves for a time when this movement might gain so much momentum that it might result in a complete change in and of our life-world and education. This might be the case sooner than later. Educators and educationists have to be prepared; education should be geared well in advance to face the anti-neoliberal challenges that might be lurking around the corner.

\section{Acknowledgements Competing interests}

The author declares that he has no financial or personal relationships which may have inappropriately influenced him in writing this article.

\section{References}

Adams, F., 2006, 'Managerialism and higher education governance: Implications for South African Universities?' South African Journal of Higher Education 20(1) 3-14. https://doi.org/10.4314/sajhe.v20i1.25554

Ball, S.J., 2003, 'The teacher's soul and the terror of performativity', Journal of Education Policy 18(2), 215-228. https://doi.org/10.1080/0268093022000043065 Bezuidenhout, A., 2016, 'Dangerous falsehoods', Beeld, 22 November 2016, p. 17. Bloomberg, 2016, 'Globalisation has to adapt', Beeld Sakenuus, 5 December 2016, p. 13.

Boas, T. \& Gans-Morse, J., 2009, 'Neoliberalism: From new liberal philosophy to antiliberal slogan', Studies in Comparative International Development 44(2), 137-161. https://doi.org/10.1007/s12116-009-9040-5

Byram, M., 2010, 'Linguistic and cultural education for Bildung and Citizenship', The Modern Language Journal 94(2), 317-321. https://doi.org/10.1111/j.15404781.2010.01024.x

Byrnes, H., 2010, 'Revisiting the role of culture in the foreign language curriculum', The Modern Language Journal 94(2), 315-317. https://doi.org/10.1111/j.15404781.2010.01023.x

Cele, G. \& Koen, G., 2003, 'Student politics in South Africa - An overview of key developments', Cahiers de la Recherce sur l'education et les savoirs (2), 201-303, viewed 3 May 2016, from https://cres.revues.org/1517 
Christie, P., 2016, 'Educational change in post-conflict contexts: Reflections on the South African experience 20 years later', Globalisation, Societies and Education 14(3), 434-446. https://doi.org/10.1080/14767724.2015.1121379

Cloete, N., 2016, 'A "third force" in higher education student activism', University World News 4 March 2016. Issue \#403, viewed 3 May 2016, from http://www. universityworldnews.com/article.php?story $=2016030410040021$

Comte-Sponville, A., 2005 The little book of philosophy, Vintage/Random House, London.

Conradie, E.M., 2011, 'Knowledge for sale? The impact of a consumerist hermeneutics on learning habits and teaching practices in higher education,' Koers 76(3), 423446. https://doi.org/10.4102/koers.v76i3.36

Diedericks, M., 2016, 'Bou Christelike onderwys aan die stad van Babel of aan die stad van God?' Roeping en Riglyne 64(2), 1-6.

Fevre, R., 1997, Some sociological alternatives to human capacity theory and their implications for research on post-compulsory education and training, Working implications for research on post-compulsory educ
Paper \#3, School of Education, Cardiff University.

Gaughan, A.J., 2016, 'Five things that explain Donald Trump's stunning presidential election victory', Mail \& Guardian, viewed 18 November 2016, from mg.co.za/ article/2016-11-09-five-things-that-explain-donald-trumps-stunningpresidential-election-victory

Grayling, A.C., 2010, Thinking of answers, Bloomsbury, London.

Hall, S., 2011, 'The neoliberal revolution', Cultural Studies 75(6), 705-728. https://doi. org/10.1080/09502386.2011.619886

Huntington, S.P., 2005, Who are we? The challenges to America's national identity, Simon and Schuster Paperbacks, New York.

Jansen, J.D., 2009, 'Intellectuals, the state and universities in South Africa', in W. Gumede \& L. Dikeni (eds.), The poverty of ideas, pp. 143-152, Jacana Media, Sunnyside.

Jones, C., Parker, M. \& Ten Bos, R., 2005, For business ethics, Routledge, London. ISBN 0415311357.

Kenny, A., 2012, Western philosophy, Clarendon Press, Oxford.

Lyotard, J.F., 1984, The postmodern condition: A report on knowledge, vol. 10, Manchester University Press, Manchester.

Maistry, S., 2014, 'Education for economic growth: A neoliberal fallacy in South Africa!' Alternation 21(1), 57-75.

Mahlomaholo, S., 2014, 'Education researchers as bricoleurs in the creation of sustainable learning environments', Perspectives in Education 32(4), 171-183.
Marois, T. \& Pradello, L., 2005, Polarising development - Introducing alternatives to neoliberalism and the crisis, Pluto Press, London. ISBN 978074531.

Naidoo, P., 2009, 'Taming the young lions: The intellectual role of youth and student movements after 1994', in W. Gumede \& L. Dikeni (eds.), The poverty of ideas, pp. 152-168, Jacana Media, Sunnyside.

Nussbaum, M.C., 2011, Creating capabilities. The human development approach, The Belknap Press of Harvard University Press, Cambridge, MA.

Palley, T.I., 2004, 'From Keyensianism to neoliberalism: Shifting paradigms in economics', Foreign Policy in Focus (FPIF), viewed 3 October 2016, from fpif.org/ from_keyensianism_to_neoliberalism_shifting_paradigms_in_economics/

Plaut, M. \& Holden, P., 2012, Who rules South Africa? Jonathan Ball Publishers, Johannesburg.

Rabe, L., 2016, 'Beware of fake news', Beeld Middelblad, 29 November 2016, p. 19.

Rosenzweig, R., 1994, 'The permeable university: Academic life in an age of special interests', Interchange 25(1), 11-17. https://doi.org/10.1007/BF01447188

Roy, A., 2014, Capitalism: A ghost story, Verso Books, London.

Rustin, M., 2016, 'The neoliberal university and its alternatives', Soundings 63, 147176. https://doi.org/10.3898/136266216819377057

Shenk, T., 2015, Booked \#3. What exactly is Neoliberalism? Interview with political scientist Wendy Brown.) Dissent, viewed 3 October 2016, from https://www. dissentmagazine.org/blog/booked-3-what-exactly-is-neoliberalims-wendybrown-undoing-the-demos

Solomon, H., 2016, 'Hopeless SA?' Paper Read at the Bloemfontein Study Group of the SA Academy, Bloemfontein, 24th November 2016.

Sparkes, A.C., 2007, 'Embodiment, academics, and the audit culture: A story seeking consideration', Qualitative Research 7(4), 521-550. https://doi.org/10.1177/ 1468794107082306

Stoker, H.G., 1967, Oorsprong en Rigting II, Tafelberg, Cape Town.

Tan, E., 2014, 'Human capital theory: A holistic criticism', Review of Educationa Research 84(3), 411-445. https://doi.org/10.3102/0034654314532696

Welch, A.R., 1998, 'The cult of efficiency in education: Comparative reflections on the reality and the rhetoric', Comparative Education 34(2), 157-175. https://doi. org/10.1080/03050069828252

Wright, R., 2009, The evolution of God, Little, Brown and Company, New York. 